\title{
On the occurrence and naturalization of Amaranthus hypochondriacus (Amaranthaceae) in some European countries, with notes on its climatic features
}

\author{
Duilio lamonico $^{1}$ (1) , Paola Fortini ${ }^{2}$ (i) \& Amara Noor Hussain ${ }^{2}$ (1)
}

Key words: Amaranthus, Europe, new record, status of naturalization.

Ključne besede: Amaranthus, Evropa, nova nahajališča, status naturalizacije.
Corresponding author:

Duilio Iamonico

E-mail: d.iamonico@yahoo.it

Received: 16. 7. 2021

Accepted: 13. 12. 2021

\begin{abstract}
The occurrence and invasion status of Amaranthus hypochondriacus in Belarus, Estonia, Italy, the Netherlands, and the North Caucasus were discussed. For Italy, we change the status from casual to naturalized based on living populations which are able to sustain themselves for 5 and over 20 years. Concerning the other countries, we clarified the invasion status of the species (inconsistently reported in literature) indicating it as a casual alien in Belarus, Estonia, and the North Caucasus and naturalized in the Netherlands. Climatic data of the European stations in which Amaranthus hypochondriacus was found were compared with those referring to the native distribution area (Mexico and southeastern regions of the US). The occurrence of the species in Europe appears to be facilitated by the temperate climate (Dutch and Italian localities), which also characterizes the native distribution area (N-America). The occurrence of the species in Estonia, the Netherlands, and the North Caucasus is interesting. In fact, although the types of climates ("Cold, Dfb" and "Temperate, Cfb") occur in America (northeastern US and central Mexico), there are some differences in precipitation and temperature values, i.e. lower mean precipitation [644.1 $\mathrm{mm}$ (Estonia) vs. $1119 \mathrm{~mm}$ (N-America); climate Dfb] and lower mean temperature $\left[9.7-11.1{ }^{\circ} \mathrm{C}\right.$ (Netherlands and North Caucasus) vs. $15.3{ }^{\circ} \mathrm{C}$ (Mexico); climate Cfb].
\end{abstract}

Izvleček

V članku obravnavamo pojavljanje in status invazivnosti vrste Amaranthus hypochondriacus v Belorusiji, Estoniji, Italiji, na Nizozemskem in Severnem Kavkazu. Za Italijo smo spremenili status vrste iz prehodne v naturalizirano vrsto na osnovi populacij, ki so obstale od 5 do več kot 20 let. Za ostale države smo opredelili status invazivnosti, ki so ga v literaturi navajali nedosledno. V Belorusiji, Estoniji in Severnem Kavkazu je vrsta prehodna, na Nizozemskem pa naturalizirana. Podatke evropskih klimatskih postaj, kjer se pojavlja vrsta Amaranthus hypochondriacus, smo primerjali s podatki z naravnega območja pojavljanja (Mehika in jugovzhodna območja ZDA). Pojavljanje vrste v Evropi je povezano z zmernim podnebjem (lokacije na Nizozemskem in v Italiji), ki je značilno tudi za naravno območje pojavljanja (severna Amerika). Nahajališča na Nizozemskem, Estoniji in Severnem Kavkazu so zanimiva. Čeprav so podnebni tipi (“mrzlo, Dfb” in “zmerno, Cfb”) značilni za Ameriko (severovzhodni del ZDA in srednja Mehika), pa obstajajo določene razlike v količini padavin in temperaturah, t. j. spodnje povprečne količine padavin [644,1 mm (Estonija) vs. $1119 \mathrm{~mm}$ (severna Amerika); podnebni tip Dfb] in spodnje povprečne temperature [9,7$11,1^{\circ} \mathrm{C}$ (Nizozemska in Severni Kavkaz) vs. $15,3^{\circ} \mathrm{C}$ (Mehika); podnebni tip Cfb].

1 Garden of the Apennine Flora of Capracotta, Capracotta (Isernia), Italy.

2 Department of Bioscience and Territory, University of Molise, Pesche (Isernia), Italy. 


\section{Introduction}

The genus Amaranthus L. (Amaranthaceae Juss. in the strict sense) contains 70-75 species, the majority of which are native to the Americas (Hernández-Ledesma et al., 2015; Bayón, 2015). Several species are used as a food, medicines, or ornamentals and are able to escape from cultivation causing a negative impact on agricultural systems, mainly due to their high seed production and resistance to herbicides, observed at least in some species (see e.g., Tranel \& Trucco, 2009; Iamonico, 2010a; Heap, 2014; Das, 2016).

The taxonomy of Amaranthus is complex because of its phenotypic and genotypic variability and some other factors (see e.g., Costea et al., 2001; Pinto \& Velasquez, 2010; Bayón, 2015; Iamonico, 2015a; Stetter \& Schmid, 2017; Waselkov et al., 2018), which resulted in nomenclatural confusions and misapplication of names (see examples considered in: Iamonico, 2016a; Iamonico, 2016b; Iamonico, 2016c; Iamonico, 2020a; Iamonico, 2020b; Iamonico, 2020c; Iamonico \& Palmer, 2020; etc.).

The infrageneric classification proposed by Mosyakin \& Robertson (1996), who recognized three subgenera based on the morphology and chorology of the various taxa [subgenus Acnida (L.) Aellen ex K.R. Robertson (with three sections), subgenus Albersia (Kunth) Gren. et Gord. (with four sections), and subgenus Amaranthus (with three sections and two subsections)] only partly agrees with the new molecular phylogenetic data presented by Stetter \& Schmid (2017) and Waselkov et al. (2018). However, the authors were aware of the preliminary nature of their classification scheme and commented that "a complete system of the genus can be worked out only as part of a taxonomic revision at species level on a worldwide basis, because proper placement of many taxa, especially those native to South America, Australia and Africa, is not completely clear yet" and that the "present article is intended to provide a preliminary outline of the infrageneric classification of Amaranthus, mainly of the subgenera Amaranthus and Acnida..." (Mosyakin \& Robertson, 1996: 275).

As a part of the ongoing investigations of genus Amaranthus for the European flora (by DI, see e.g., Iamonico, 2010, Iamonico, 2016, Iamonico, 2017, Iamonico, 2020a, Iamonico, 2020b, Iamonico \& Galasso 2018) and the $\mathrm{PhD}$ research by $\mathrm{ANH}$ (tutor PF, co-tutor DI; see e.g., Laface et al., 2020; Galasso et al., 2021), we present here a note concerning Amaranthus hypochondriacus L. including some floristic novelties for Estonia (first national records), Italy (first discovered naturalized populations at national scale), Netherlands (confirmation of the occurrence), Belarus and the North Caucasus (clarification of the status of naturalization). Notes on the climatic fea- tures of the European sites in which $A$. hypochondriacus was here recorded in comparison with the climate of the native distribution area of the species, were also given.

\section{Material and Methods}

This study is based on personal field surveys (2015-2020), review of the pertinent literature, and examination of the specimens preserved in the herbaria FI, GH, IS, MSNM, MW, NY, P, RO, TAA, U, URT, and US (codes according to Thiers 2021 [continuously updated]). The plants observed in the field are used to describe the species.

Alien status and definitions of categories are according to Galasso et al. (2018).

Climatic data derive from the updated Köppen-Geiger's climate classification by Zepner et al. (2020), whereas bioclimatic maps of America and Europe by Rivas-Martínez et al. (2007a, 2007b). We chose at least one locality per climate type, the localities found based on the distributional data of the specimens examined, as well as the indication by Sauer (1967) and Costea et al. (2001).

\section{Results and Discussion}

\section{Distribution notes}

\section{Belarus}

Amaranthus hypochondriacus was reported for Belarus by Iamonico (2015b) in his treatment of the genus Amaranthus for the Euro+Med Plantbase project. However, the status as alien was not specified based on literature checked at that time (i.e. Mosyakin, 1996; Tzvelev, 2012). Further literature sources were found during the present research, but the status of the species was not precisely specified. For example, Dubovik et al. (2018) recorded A. hypochondriacus in a wasteland in Liozno town (Liozno district, Vitebsk region, NE Belarus) in October 2017, but they did not report its alien status. Just one year later, the same author (Dubovik, 2019: 198) included the species in a list of taxa "potentially invasive" (a rather standard category in East European literature), without any explanation of this definition. In the online database of the Flora of Belarus (Plants of Belarus, 2003-2021), A. hypochondriacus is reported as cultivated species only (see also Vlasava et al., 2010; Loban, 2016; Loban \& Kot, 2017). Several East European articles which cite this species, usually mention just a few plants near places of cultivation or on garden waste heaps [e.g., just several plants on waste heaps mentioned in literature for Ukraine (Zviagintseva, 2013; Boiko \& Kolomiychuk, 2015) or in Russia (Mikhailovich \& Akramovich, 2017)].

Amaranthus hypochondriacus can be considered as casual alien species for Belarus (Table 1). 


\section{Estonia}

According to Iamonico (2015b), 9 species (10 taxa) occur in Estonia, Amaranthus hypochondriacus being not included. This species has not been mentioned in the checklist of the Estonian flora (Kukk, 1999). We traced six specimens deposited at the herbarium TAA (images available at https://elurikkus.ee/generic-hub/occurrences/ search?q=1sid:730857\#records), collected between 1971 and 2017, and clearly identifiable as A. hypochondriacus according to the current taxonomic concept in Amaranthus (see e.g., Mosyakin \& Robertson, 2003; Iamonico, 2015a). These specimens are included in the eElurikkus online database (available at https://elurikkus.ee/en/) where, however, no invasion status is reported for the species (see also Pärtel et al., 2021). We here consider $A$. hypochondriacus as a casual alien in the country (Table 1).

Specimina Visa: ESTONIA. Harjumaa, Tallinna linn, Pääsküla prügimägi, 25.IX.1989, T. Ploompuu s.n. (TAA0021313!). Järvamaa, Türi vald, Vissuvere küla, 01.X.2017, O. Luuk s.n. (TAA0142895!). Pärnumaa, Pärnu linn, Strandi taga, 27.VII.2017, I Tammekänd s.n. (TAA0143390!). Pólva, Kanepi vald, Kanepi. Vana haldusyksus, 27.VIII.1971, L. Piblapuus.n. (TAA0021284!). Saaremaa, Pihtla vald, Sutu küla, 12.VIII.2016, T. Kukk et M. Mesipuu s.n. (TAA0136967!); Ibidem (TAA0136968!).

\section{Italy}

Amaranthus hypochondriacus is currently considered as a casual alien in Italy, occurring in most of the regions (Galasso et al., 2018) and growing in human-made habitats (Iamonico 2015a).

In 2016, one of us (DI) discovered a new population of Amaranthus hypochondriacus in Lazio region (central Italy) in Rome city (Province of Rome). This population, originally consisted of 2-3 individuals growing along a ditch (named "Acqua Mariana"1) occurring in the Acquedotti locality of the Appia Antica Regional Park (Figure 1A). During the recent years, the Rome site was visited (last observations in October 2021) and new plants occurred reaching to about 15 individuals. So, the population spread. It is worth noting that the site is subject of recurring swaths during each year (usually twice a year).

The second population was discovered in the territory of Piglio Municipality (Province of Frosinone, southern Lazio) in the abandoned rail stop station "Piglio" which was part of the railway "Roma-Fiuggi-Alatri-Frosinone" (a total of $137 \mathrm{~km}$ in length, of which only a short section included in the Municipality of Rome is nowadays operational; the station is abandoned since about 24 years).

\footnotetext{
1 This ditch is a perennial water course (river flow varying from 150 to 400 l/s) that originates on the Molara valley in the Castelli Romani Regional Park (Capelli 2015) about $20 \mathrm{~km}$ (to south) from the Acquedotti locality.
}

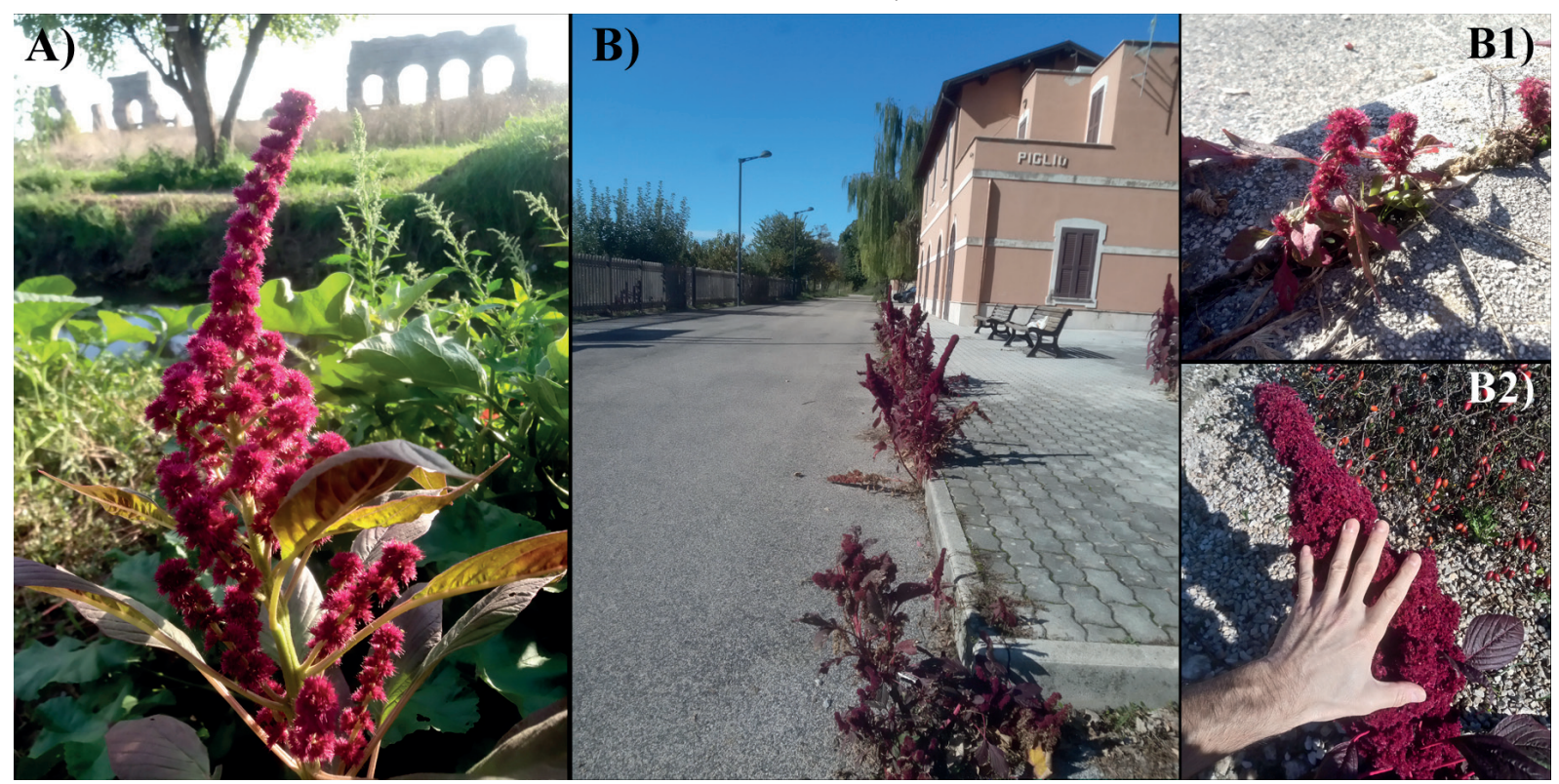

Figure 1: Amaranthus hypochondriacus in Lazio region (central Italy). A) individual in the Acquedotti località (Appia Antica Regional Park, Province of Rome); B) part of the population occurring in Piglio abandoned rail stop station: B1) seedling, B2) synflorescence. Photos by D. Iamonico, dated 28 October 2020.

Slika 1: Amaranthus hypochondriacus v regiji Lazio (osrednja Italija). A) primerek z lokacije Acquedotti (Regionalni park Appia Antica, provinca Rim); B) del populacije na zapuščeni železniški postaji Piglio: B1) klice, B2) socvetje. Fotografije D. Iamonico, 28. oktobra 2020. 
The population is composed of approximately 150 individuals, thus representing the largest Italian population, according to our knowledge (Figure 1B). We found plants in all stages of development, both by age and size, from seedling about $5 \mathrm{~cm}$ to mature individuals up to about $2.5 \mathrm{~m}$ tall. Also, the synflorescences highly vary in length, from $2-3$ to $50-60 \mathrm{~cm}$. The first observation was made in October 2019. During the field surveys, we discussed the occurrence of Piglio's population with some locals who said that they had seen these plants since about 20 years.

We assess these two populations from Lazio region as naturalized and this datum represents the first one for Italy (Table 1).

Specimina Visa: ITALY. Lazio, Rome Province, Rome city, Appia Antica Regional Park, locality Acquedotti, ditches, $56 \mathrm{~m}$ a.s.l., 06.X.2016, D. Iamonico s.n. (RO!); ibidem, 18.X.2020 (RO!); Frosinone Province, Piglio Municipality, abandoned rail station, 15.X.2019, D. Iamonico s.n. (RO!); ibidem, 28.X.2020, D. Iamonico \& A. Noor Hussain s.n. (RO!, IS!).

\section{Netherlands}

Literature data about the occurrence of Amaranthus hypochondriacus in Netherlands are inconsistent. For example, the Euro+Med PlantBase does not report the species for the country (Iamonico, 2015b) whereas it was indicated as "introduced" for Netherlands in POWO (2021), although no specific literature was cited there. The oldest Flora of Netherlands by Heuckel (1883: 284-285) did not include $A$. hypochondriacus, whereas the taxon was cited as "adv." (to interpret as "alien") in the subsequent Heuckel's edition (Heuckel, 1900: 167, sub A. hybridus subsp. hypochondriacus) and in the recent work by Duistermaat (2020). Tamis et al. (2003: 122-123) did not again indicate $A$. hypochondriacus for the country in the recent updating of the Netherlands Flora. Dirkse et al. (1983), who studied in detail the occurrence and taxonomy of $A$. hybridus $\mathrm{L}$. and $A$. bouchonii Thell. in the Netherlands, recognized $A$. hypochondriacus as a syno- nym of $A$. hybridus. However, on the basis of the description given by Dirkse et al. (1983: 75), the plants observed by these authors morphologically match the current concept of $A$. hybridus s.s. (see e.g., Mosyakin \& Robertson, 2003; Iamonico, 2015a). Finally, the online database of the Dutch flora (NDFF, 2015; Waarneming, 2021) reports this species as occurring in Netherlands, also providing several pictures (field photographs) of plants growing in all the twelve Dutch European Provinces: Drenthe [Assen (Figure 2A), Veenoord, and Zuidlaren], Gelderland (surroundings of Winterswijk), Flevoland (Almere), Friesland (Augsbuurt, Stiens, and Waadhoeke), Groningen (Glimmen and Groningen), Limburg (Maastricht), North Brabant (Breda, Heeze, and Overloon), North Holland (Alkmaar, Amsterdam, and Purmerend), Overijssel (Borne, Steenwijk, and Zwolle), South Holland [Den Haag, Katwjik (Figure 2B), Leiden, Leidschendam, Oegstgeest, Rockanje, Veenendaal, and Voorschoten], Utrecht (Bilthoven, Nieuwegein, and Utrecht), and Zeeland (Aagtekerke and Noordwelle). Habitats in which $A$. hypochondriacus was observed are: margins of cultivated fields, meadows, roads, uncultivated lands, and urban parks. We can confirm that all these plants were correctly identified.

Concerning herbarium specimens, many exsiccata collected in the Netherlands and labelled as Amaranthus hypochondriacus, are deposited at L, U, and WAG (see Naturalis, 2021). On the basis of our examination, we could confirm only a few identifications, the others being erroneous (specimens referable to $A$. hybridus or $A$. cruentus L.) according to the current concept in Amaranthus (see e.g., Mosyakin \& Robertson, 2003; Iamonico, 2015a).

Finally, concerning the status of naturalization of Amaranthus hypochondriacus in the Netherlands, it should be noted that the first reliable observation of the species was in 2006 and the number of observations greatly increased since 2018, especially since 2019 (see Waarneming, 2021). On the basis of the data reported in Waarneming's database, this increase appears to be more or less related

Table 1: Occurrence and invasion status of Amaranthus hypochondriacus in the studied european countries.

Tabela 1: Pojavljanje in status invazivnosti vrste Amaranthus hypochondriacus v preučevanih evropskih državah.

\begin{tabular}{llll} 
COUNTRY & Locality & $\begin{array}{l}\text { Invasion status according to } \\
\text { literature and current definitions }\end{array}$ & $\begin{array}{l}\text { Invasion status according } \\
\text { to the present research }\end{array}$ \\
\hline $\begin{array}{llll}\text { BELARUS } \\
\text { ESTONIA }\end{array}$ & $\begin{array}{l}\text { Liozno town (Liozno district) } \\
\text { Harjumaa, Järvamaa, Pärnumaa, } \\
\text { Pólva, Saaremaa counties }\end{array}$ & $\begin{array}{l}\text { not precisely specified } \\
\text { not precisely specified }\end{array}$ & $\begin{array}{l}\text { casual } \\
\text { casual }\end{array}$ \\
NETHERDLANDS & Bergen Op Zoom (North Brabant) & $\begin{array}{l}\text { contrarsting data (species not recorded } \\
\text { or, if occurring, not precisely specified) }\end{array}$ & naturalized \\
ITALY & Rome city, Piglio town (Latium region) & casual & naturalized \\
RUSSIA & Novorossyisk (Krasnodar Krai) & not precisely specified & casual \\
(North Caucasus) & Soči city (Krasnodar Krai) & & \\
\hline
\end{tabular}




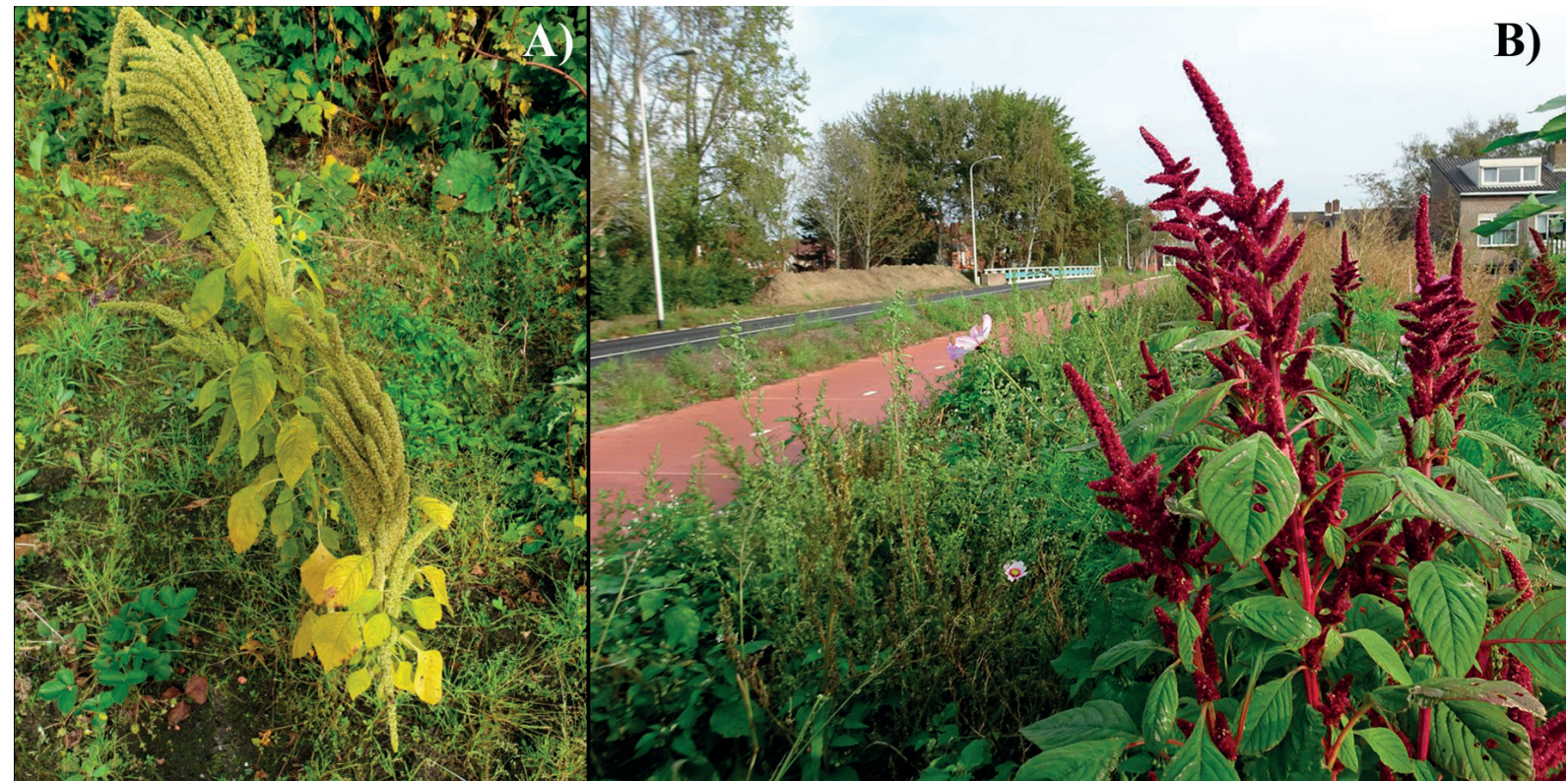

Figure 2: Amaranthus hypochondriacus in the Netherlands. A) locality Noorderpark, Municipality Assen, Province Drenthe (photo by Guus de Vries, 04 October 2020), B) locality Katwijk aan Zee, Municipality Katwijk, Province South Holand (photo by Jelle van Dijk, 13 october 2013 ).

Slika 2: Amaranthus hypochondriacus na Nizozemskem. A) lokacija Noorderpark, občina Assen, provinca Drenthe (fotografija Guus de Vries, 4. 10. 2020) B) lokacija Katwijk aan Zee, občina Katwijk, provinca South Holand (fotografija Jelle van Dijk, 13. 10. 2013).

to the number of observers $(1-4$ per year in the period 2006-2017; 7 in 2018; 23 and 24 in 2019 and 2020, respectively). However, the number per year of observed individuals (total number in the period 2006-2020 is 364) did not vary proportionally with the number of observers. For example, 111 individual plants were observed in 2010 by 3 observers, whereas 115 individual plants were registered by 24 observers in 2020 (Figure 3). This fact leads us to consider a real spreading of at least some populations of $A$. hypochondriacus in the Netherlands and, therefore, we here assess the species as naturalized alien for the country (Table 1).

Specimina Visa: NETHERLANDS. In ruderatis Franssik, s.d, P. J. F. Schur s.n. (L1684649!). South Holland, Leiden, s.d., s.c s.n. (L1684572!).

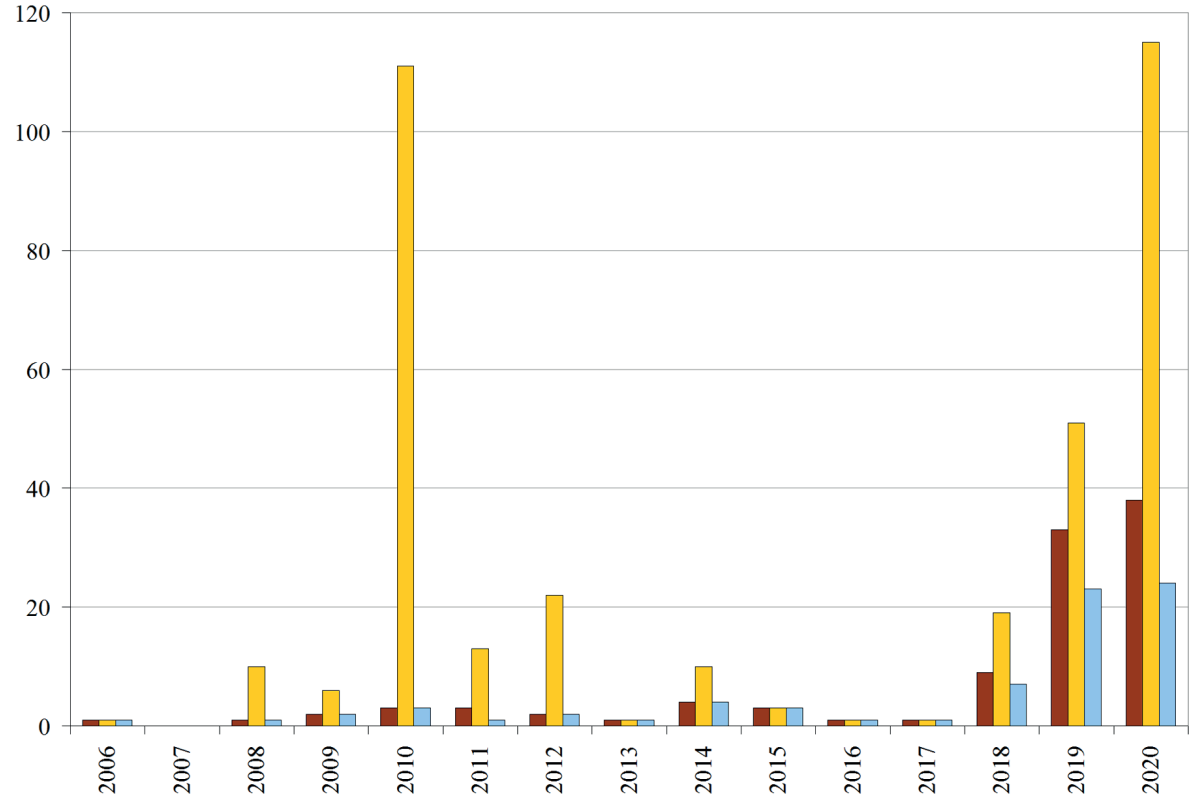

Figure 3: Comparison among number of observations (brown bars), number of individuals observed (orange bars), and number of person who observes the plants (light blue bars) of Amaranthus hypochondriacus in the Netherlands during the period 2006-2020.

Slika 3: Primerjava med številom zabeleženih lokacij (rjavi stolpec), številom posameznih osebkov (oranžni stolpec) in številom opazovalcev (svetlomodri stolpec) vrste Amaranthus hypochondriacus na Nizozemskem v obdobju 2006-2020. 


\section{North Caucasus}

The North Caucasus is the northern part of the Caucasus region within the Russian Federation located among the Black Sea and the Sea of Azov on the west, the Caspian Sea on the east, and Georgia and Azerbaijan on the South. As part of the Russian Federation, the North Caucasus consists of the following administrative units (from west to east): Krasnodar Krai (bordering the Black Sea and the Sea of Azov) and Stavropol Krai, republics of KarachayCherkessia, Kabardino-Balkaria, North Ossetia-Alania, Ingushetia, Chechnya, and Dagestan (the latter bordering the Caspian Sea). This map corresponds to the "Russian Caucasia" [code Rf (CS)] in the Euro+Med Plant Base (Euro+Med 2006-).

Amaranthus hypochondriacus was reported by Iamonico (2015b) for Rf(CS) as an alien species with "status unknown" based on Menitsky (2012). This latter author stated "sometimes escapes [from cultivation]" (аs “иногда

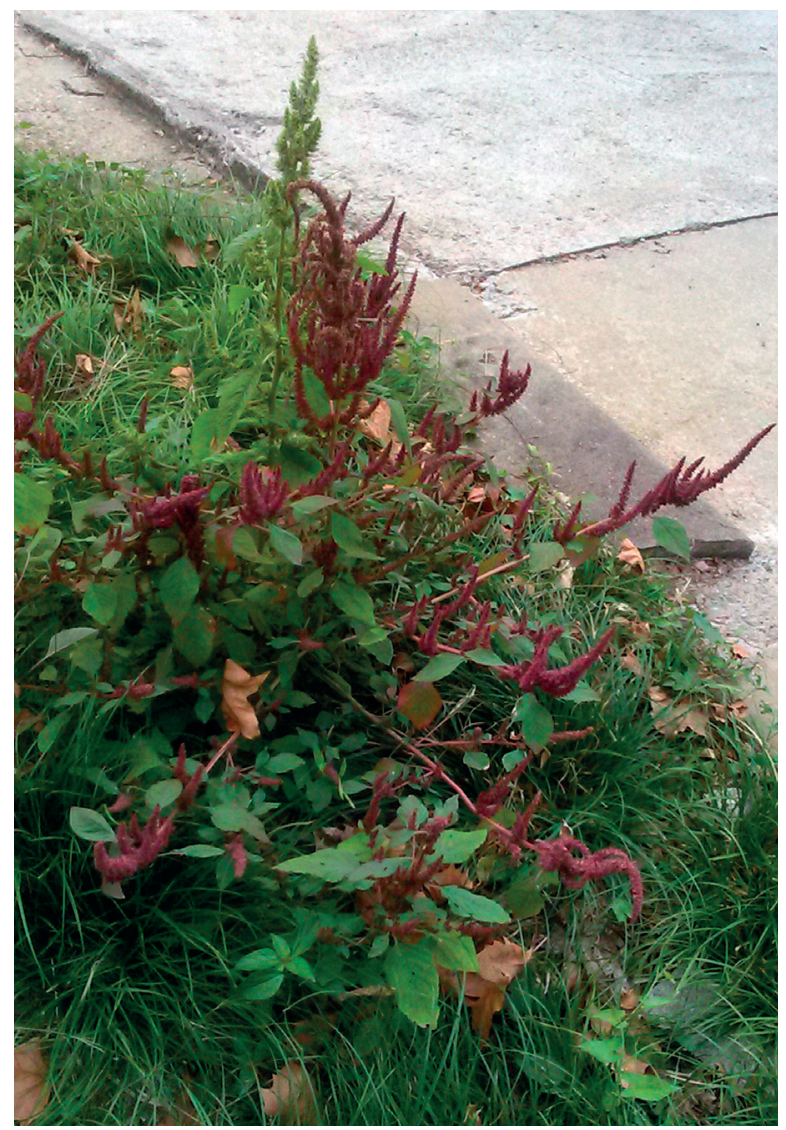

Figure 4: Amaranthus hypochondriacus in Soči city, along Leningradskaya street (Krasnodar Krai, North Caucasus). Photo by Michail Orlov, dated 03 october 2019.

Slika 4: Amaranthus hypochondriacus v mestu Soči, ob Leningradski ulici (Krasnodarska pokrajina, Severni Kavkaz). Foto Michail Orlov, 3. 10. 2019. дичает") which would means that the species is cultivated and was occasionally registered as escaped (S. Mosyakin pers. comm.). The record of Menitsky (2012) was directly based on data of Zernov (2006), who reported A. hypochondriacus for the Sochi landscape and floristic region (Region II in his book) of the Northwestern Caucasus, as cultivated and occasionally escaped. Also, Zernov (2013: 208) later briefly reported $A$. hypochondriacus specifically for the Southern stretch of the Russian Black Sea coast (within the limits of the municipality of Sochi, also known as the Greater Sochi region) as "cultivated as ornamental, sometimes occurring as escaped". Another relevant work is Conspectus Florae Caucasi Rossicae (Ivanov, 2019) where the author reported $A$. hypochondriacus as “Адвент." (= адвентивный = adventitious, adventive, alien) and rare ([R.], see Ivanov, 2019: 9).

Mainly general information about the alien status of A. hypochondriacus was provided in available East European (Russian, Ukrainian, Belarusian, etc.) works.

We traced five herbarium specimens at MW (barcodes MW0664012, MW0664013, MW0664014, MW0664015, MW0664016) which bear plants of Amaranthus hypochondriacus collected in the North Caucasus. We can confirm the identifications of these plants.

Furthermore, there is a picture on the website iNaturalist (https://www.inaturalist.org/observations/33794394) made by Michail (Mikhail) Orlov (Михаил Орлов) in Soči (Sochi) city (Krasnodar Krai; coordinates: 43.65243 N, 39.656438 E) which shows a plant of Amaranthus hypochondriacus growing in an uncultivated field along Leningradskaya Street (Figure 4). M. Orlov informed me that he has seen just a few individual plants.

All these evidences confirm the occurrence of the species in the North Caucasus as a casual alien (Table 1).

Specimina Visa: NORTHERN CAUCASUS. Russia, Krasnodar Frai \& Adygea, $170 \mathrm{~m}$ a.s.1., 07.IX.2008, А. Серегин, Л. Аиуркова, 3. Винокурова С-1036 (MW0664012!); Black Sea Shore, from Novorossyisk to Adler, 20.VII.2005, А.С. Зернов 4433 (MW0664013); ibidem (MW0664015); Black Sea Shore, from Novorossyisk to Adler, 16.VIII.2002, A.C. Зернов 1727 (MW0664014); Black Sea Shore, from Novorossyisk to Adler, 30.VIII.2008, Шведчикова H. s.n. (MW0664016).

\section{Climatic and bioclimatic data}

Amaranthus hypochondriacus (belonging to Amaranthus subgen. Amaranthus sect. Hybrida Mosyakin \& K.R. Robertson sensu Mosyakin \& Robertson 1996) is a species native to Mexico and southwestern North America (Sauer, 1967; Mosyakin \& Robertson, 2003; POWO, 
2021) and cultivated as ornamental in both the Americas and the other continents where is considered as alien (see e.g., Sauer, 1967; Bao et al., 2003; SANBI, 2012; Iamonico, 2015b).

According to Zepner et al. (2020), who referred to Köppen-Geiger's climate classification (Köppen, 1936), the following main types of climates characterized the native distribution area of Amaranthus hypochondriacus (Table 2, Figure 5):

1) Tropical (type "A"): it is defined by a temperature of the coldest month $\geq 18^{\circ} \mathrm{C}$. This type of climate is found in Mexico;

2) Arid (type "B"): it is defined by the mean annual precipitation $<10 \mathrm{~mm}$. Two subtypes occur in the distribution area of Amaranthus hypochondriacus: type "BSh" ("Arid Steppe Hot") with mean annual precipitation $\geq 5 \mathrm{~mm}$ and mean annual temperature $\geq 18{ }^{\circ} \mathrm{C}$ (SW-U.S.A., Texas), and type "BSk" ("Cold semi-arid climate") with mean annual precipitation $\geq 5 \mathrm{~mm}$ and mean annual temperature $<18{ }^{\circ} \mathrm{C}$ (W-U.S.A., Arizona);

3) Temperate (type " $\mathrm{C}$ "): it is defined by a temperature of the hottest month $\geq 10^{\circ} \mathrm{C}$ and temperature of the coldest month comprises between 0 and $18{ }^{\circ} \mathrm{C}$. The main subtypes for distribution area of Amaranthus hypochondriacus are:

a. "Temperate without dry season" (subtype "Cfa"), defined by precipitation of the driest month in summer $>40 \mathrm{~mm}$ rain, and temperature of the hottest month $\geq 22^{\circ} \mathrm{C}$. This type of climate is found in the south of central-eastern-U.S.A.;

b. Temperate "Cfb": a temperate climate without a dry season and warm summer (temperature of the hottest month $<22^{\circ} \mathrm{C}$; a number of months where the temperature is above $10^{\circ} \mathrm{C} \geq 4$ ). This type of climate is found in central Mexico;

4) Cold (type "Dfb", temperate without dry season and warm summer): it is defined by the temperature of the hottest month $<22{ }^{\circ} \mathrm{C}$, temperature of the coldest $\leq$ $0{ }^{\circ} \mathrm{C}$, and 4 or more months having the average temperature is $>10^{\circ} \mathrm{C}$. This type of climate is found in the northeastern U.S.A.

Concerning the European sites involved in the present paper, the following three types of climates were identified according to Zepner et al. (2020) who, in turn, considered the Köppen-Geiger's classification (Table 1, Figure 5):

1) Temperate "Cfa" (see above for the details about temperature and precipitation): this type of climate is found in Italy;

2) Temperate "Cfb" (see above for the details about tempera ture and precipitation): this type of climate is found in the Netherlands and the North Caucasus;
3) Cold "Dfb" (see above for the details about temperature and precipitation): this type of climate is found in Estonia.

Concerning bioclimatic data (Rivas-Martínez et al., 2007a; Rivas-Martínez et al., 2007b), the native distribution area of Amaranthus hypochondriacus (see Sauer, 1967; Costea et al., 2001), is mainly characterized by the following types of bioclimates:

1) Tropical, subtypes "Xeric", "Pluviseasonal", and "Pluvial" (nos. 13, 14, and 15 in Rivas-Martínez et al., 2007a);

2) Temperate, subtypes "Xeric" (no. 31) and "Continental" (no. 32).

Regarding the European localities studies by us, according to Rivas-Martínez et al. (2007b) they are part of the Mediterranean and Temperate bioclimates. In particular, only Italian localities (Rome and Piglio) are located within the area defined by Rivas-Martínez et al. (2007) as "Mediterranean pluviseasonal oceanic" variant ${ }^{2}$, whereas the other ones are part of the "Temperate continental steppic" $^{3}$ (Estonian localities) and Temperate oceanic" 4 (Netherlands and North Caucasus localities) variants.

\section{Conclusions}

In our current study, we have reported that the distribution tendencies of Amaranthus hypochondriacus in five European countries (Belarus, Estonia, Italy, the Netherlands, and the North Caucasus), coupled with the environmental factors facilitating its presence or absence. The results obtained revealed that $A$. hypochondriacus is a naturalized alien only in regions characterized by Temperate climate (Subtypes Cfa and $\mathrm{Cfb}$ ), in Italy and the Netherlands. Our findings suggest that this the species grows more abundantly in central Italy than in other countries. It can be assumed that Subtype Cfa (climate type: $\mathrm{Cfa}$, temperature range: $7.3-16.9^{\circ} \mathrm{C}$, precipitation range: $18.9-115.0 \mathrm{~mm}$, precipitation of the driest month in summer $>40 \mathrm{~mm}$ rain, and temperature of the hottest month $\geq 22^{\circ} \mathrm{C}$ ) is more favorable for the growth of this species. In Belarus and the North Caucasus, the current status is a casual alien species. Interestingly, are the occurrence of the species in Estonia and the Netherlands or the North Caucasus where, although the types of climates (respectively, "Cold, Dfb" and "Temperate, Cfb") can be found in America (northeastern U.S.A. and central Mexico, respectively), there are some differences in precipi-

\footnotetext{
2 This variant is defined by the Annual Ombrothermic index ( $\mathrm{Io}=\mathrm{Pp} / \mathrm{Tp}$ ) $\geq 2$, and Simple Continentality index (Ic $=\operatorname{Tmax}-\operatorname{Tmin}) \leq 21^{\circ} \mathrm{C}$.

3 This variant is defined by the Io $=\geq 3.6$, and Ic $>21^{\circ} \mathrm{C}$.

4 This variant is defined by the Io $=\geq 3.6$, and $11<\mathrm{Ic}<21^{\circ} \mathrm{C}$.
} 
Table 2: Climatic data on temperatures and precipitations of the selected localities. Climate type and data according to Zepner et al. (2020).

Table 2: Klimatski podatki o temperaturi in padavinah na izbranih lokacijah. Klimatski podatki so v skladu s Zepner et al. (2020).

\begin{tabular}{|c|c|c|c|c|c|c|c|c|c|c|}
\hline \multirow{2}{*}{\multicolumn{2}{|c|}{$\begin{array}{l}\text { COUNTRY } \\
\text { (locality, administrative } \\
\text { political unit) }\end{array}$}} & \multirow[b]{2}{*}{$\begin{array}{l}\text { Climate } \\
\text { type }\end{array}$} & \multicolumn{4}{|c|}{ Temperature $\left({ }^{\circ} \mathrm{C}\right)$} & \multicolumn{4}{|c|}{ Precipitations (mm) } \\
\hline & & & Mean & Range & $\begin{array}{l}\text { Coldest } \\
\text { month }\end{array}$ & $\begin{array}{l}\text { Hottest } \\
\text { month }\end{array}$ & $\begin{array}{l}\text { Sum per } \\
\text { year }\end{array}$ & Range & $\begin{array}{l}\text { Least rainy } \\
\text { month }\end{array}$ & $\begin{array}{l}\text { Wettest } \\
\text { month }\end{array}$ \\
\hline \multirow{4}{*}{ 苋 } & ITALY (Rome, Latium) & $\mathrm{Cfa}$ & 15.5 & $7.3-23.9$ & January & August & 802 & $18.9-115.0$ & July & November \\
\hline & $\begin{array}{l}\text { NETHERDLANDS (Bergen } \\
\text { Op Zoom, North Brabant) }\end{array}$ & $\mathrm{Cfb}$ & 9.7 & $2.9-16.9$ & January & $\begin{array}{l}\text { July- } \\
\text { August }\end{array}$ & 799.6 & $47.1-81.8$ & April & November \\
\hline & $\begin{array}{l}\text { NORTH CAUCASUS } \\
\text { (Soči city, Krasnodar Krai) }\end{array}$ & $\mathrm{Cfb}$ & 11.1 & $1.6-20.4$ & January & $\begin{array}{l}\text { July- } \\
\text { August }\end{array}$ & 1358.7 & $86.8-163.6$ & July & December \\
\hline & ESTONIA (Paide, Järvamaa) & $\mathrm{Dfb}$ & 5.0 & $-6.6-16.6$ & January & July & 644.1 & $29.3-82.8$ & February & August \\
\hline \multirow{6}{*}{ 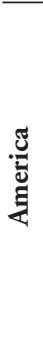 } & $\begin{array}{l}\text { MEXICO (Nocupétaro, } \\
\text { Michoacán) }\end{array}$ & A & 21.4 & $18.4-25.0$ & December & May & 1106.8 & $3.2-250.5$ & March & July \\
\hline & U.S.A. (Asherton, Texas) & BSh & 22.7 & $12.9-31.2$ & January & July & 551.3 & $27.8-86.0$ & December & May \\
\hline & U.S.A. (Winslow, Arizona) & BSk & 12.0 & $-0.9-24.9$ & January & July & 201.0 & $4.6-35.4$ & June & August \\
\hline & MEXICO (Tala, Jalisco) & $\mathrm{Cfa}$ & 22.1 & $18.1-25.7$ & January & June & 924 & $3.1-229.1$ & April & July \\
\hline & MEXICO (Tlaxco, Tlaxcala) & $\mathrm{Cfb}$ & 15.3 & $11.7-17.9$ & January & May & 701 & $0.0-192.0$ & $\begin{array}{l}\text { February, } \\
\text { December }\end{array}$ & August \\
\hline & $\begin{array}{l}\text { U.S.A. (Utica/Faa airport, } \\
\text { New York) }\end{array}$ & $\mathrm{Dfb}$ & 7.5 & $-6.8-20.6$ & January & July & 1119 & $84.3-122.8$ & 3 January & September \\
\hline
\end{tabular}

\section{Rome, Latium, Italy}

41.865N, 12.572E | Elevation: 51 m | Climate Class: Cfa | Years: 1970-2019

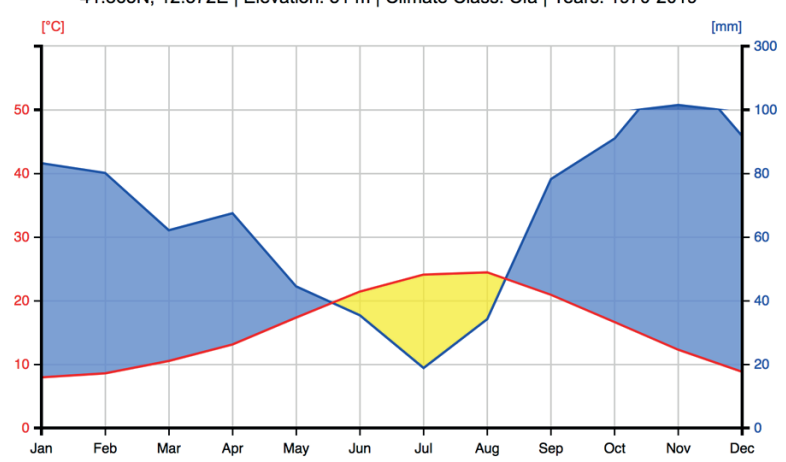

Sochi, Krasnodarskiy, Russia

43.652N, 39.657E | Elevation: 27 m | Climate Class: Cfb | Years: 1961-1990

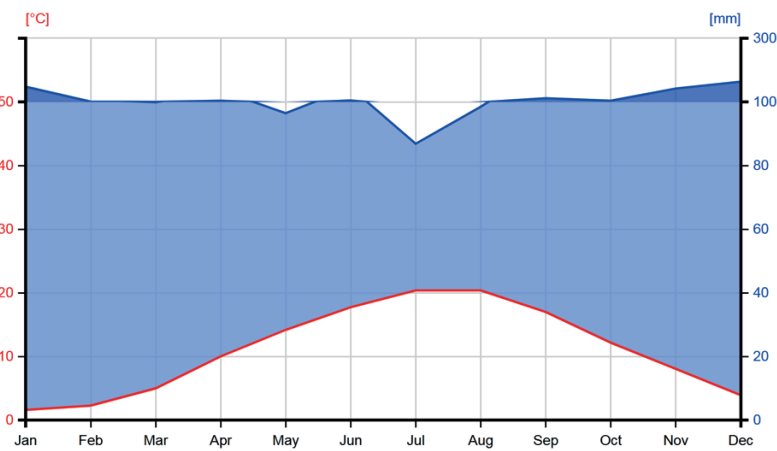

Bergen op Zoom, North Brabant, Netherlands

51.5N, 4.269E | Climate Class: Cfb | Years: 1961-1990

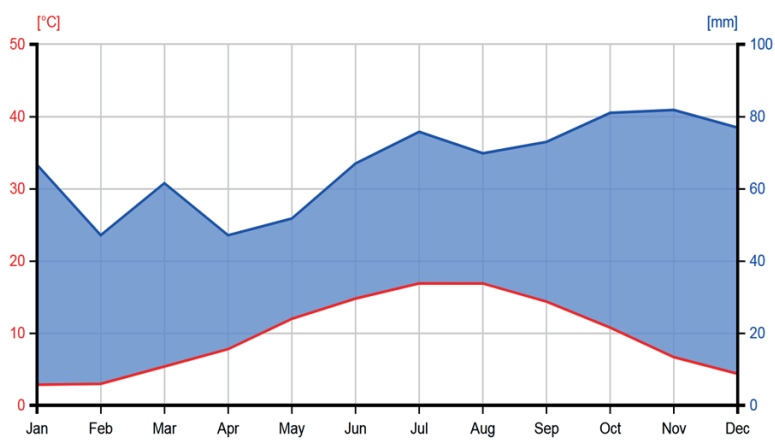

Paide, Järvamaa, Estonia

58.888N, 25.557E | Elevation: 65 m | Climate Class: Dfb | Years: 1961-1990

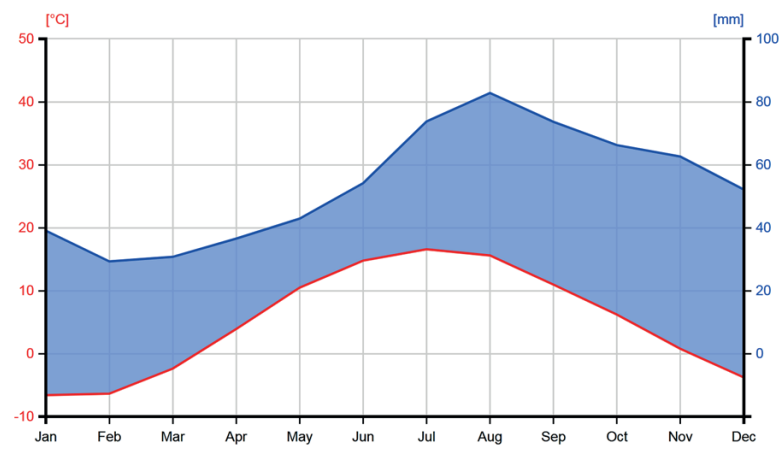

Figure 5: Walter-Lieth charts referring to the localities chosen for climatic data in the present study. From top-left to bottom-right (climatic stations ordered as in Table 2): Europe: Rome, Latium, Italy, Bergen Op Zoom, North Brabant, Netherlands, Soči city, Krasnodar Krai, North Caucasus, Paide, Järvamaa, Estonia.

Slika 5: Grafikoni po Walter-Lieth, ki prikazujejo klimatske podatke za izbrane kraje. Od zgoraj levo do spodaj desno (klimatske postaje so urejene kot v Tabeli 2): Evropa: Rim, Lacij, Italija, Bergen Op Zoom, Severni Brabant, Nizozemska, Soči, Krasnodarska pokrajina, Severni Kavkaz, Paide, Järvamaa, Estonija. 
Nocupétaro, Michoacán, Mexico

19.059N, 101.215W | Elevation: 735 m | Climate Class: A | Years: 1990-2019

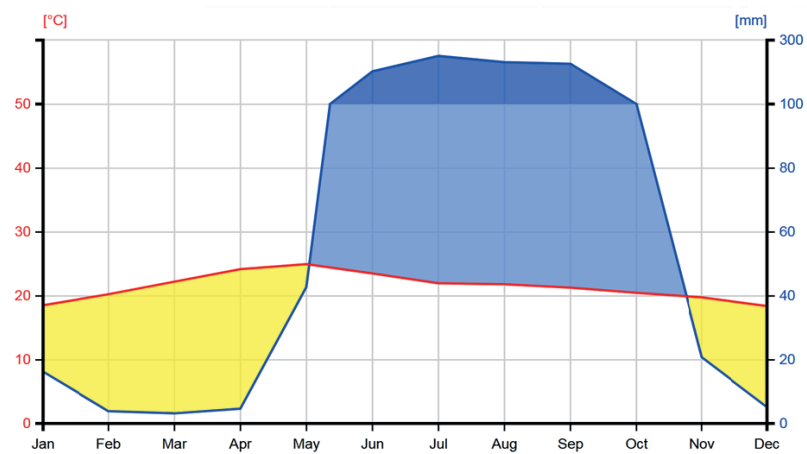

Winslow, Az., United States Of America

35.02N, 110.73W | Elevation: 1488 m | Climate Class: BSk | Years: 1961-1990

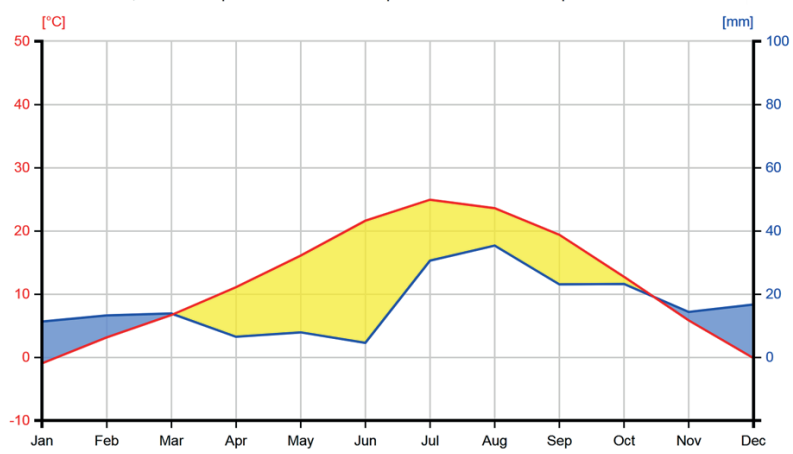

Tlaxcala, Tlax, Mexico

19.32N, 98.23W | Elevation: 2248 m | Climate Class: Cfb | Years: 1980-2001

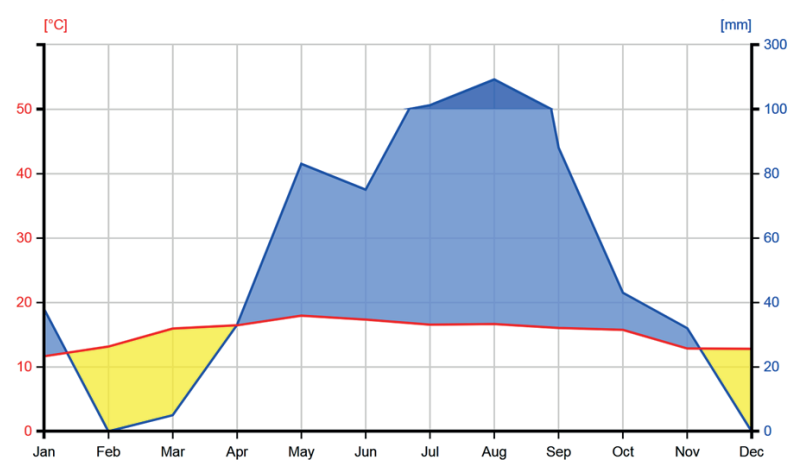

Asherton, Texas, United States

28.282N, 99.831W | Elevation: 197 m | Climate Class: BSh | Years: 1980-2001

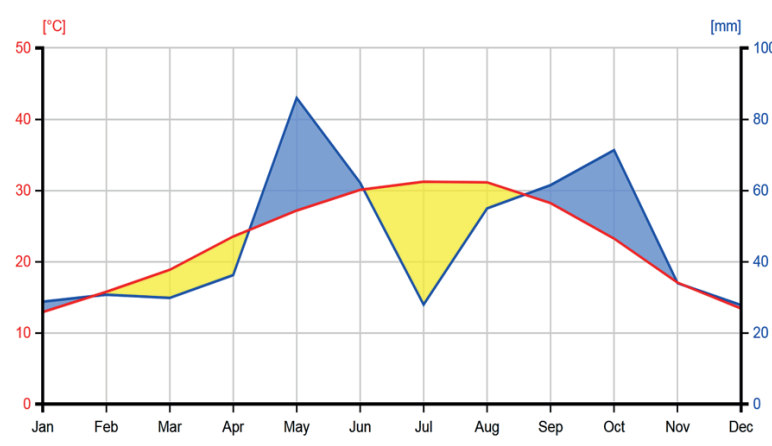

Tala, Jalisco, Mexico

20.609N, 103.742W | Elevation: 1292 m / Climate Class: Cfa | Years: 1990-2019

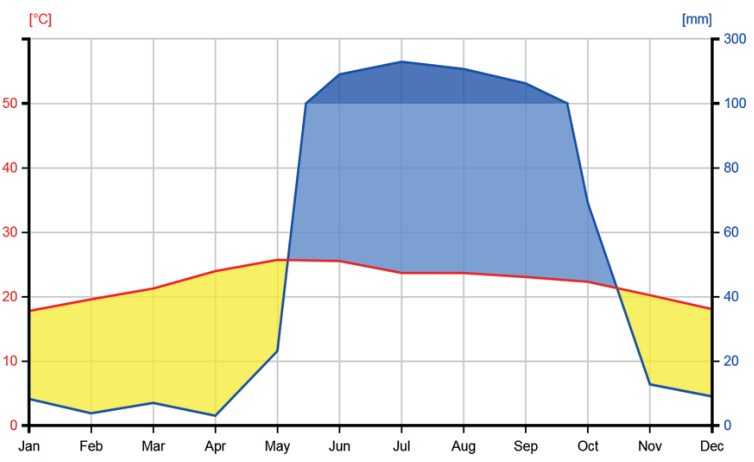

Utica/Faa Airport, United States Of America

43.15N, 75.38W | Elevation: $217 \mathrm{~m}$ | Climate Class: Dfb | Years: 1975-2004

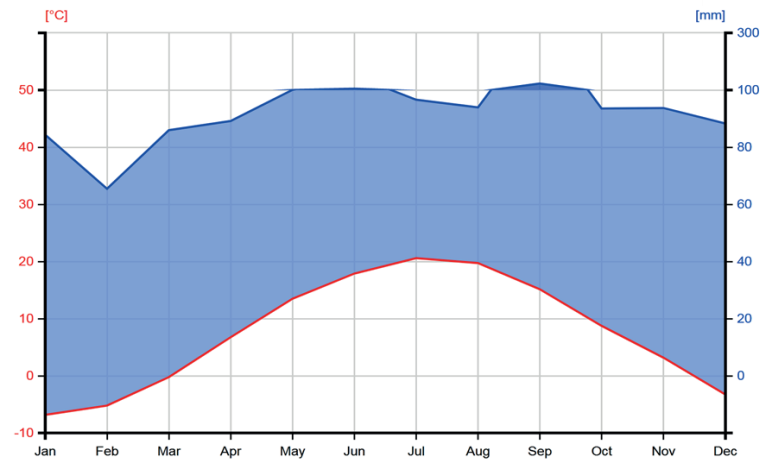

Figure 5 (continued): Walter-Lieth charts referring to the localities chosen for climatic data in the present study. From top-left to bottom-right (climatic stations ordered as in Table 2): America: Nocupétaro, Michoacán, Mexico, Asherton, Texas, U.S.A., Winslow, Arizona, U.S.A., Tala, Jalisco, Mexico, Tlaxcala, Mexico, Utica/Faa airport, New York, U.S.A.

Slika 5 (nadaljevanje): Grafikoni po Walter-Lieth, ki prikazujejo klimatske podatke za izbrane kraje. Od zgoraj levo do spodaj desno (klimatske postaje so urejene kot v Tabeli 2): America: Nocupétaro, Michoacán, Mexico, Asherton, Texas, U.S.A., Winslow, Arizona, U.S.A., Tala, Jalisco, Mexico, Tlaxcala, Mexico, Utica/Faa airport, New York, U.S.A.

tation and temperature values, i.e.: lower mean precipitation [644.1 mm (Estonia) vs. $1119 \mathrm{~mm}$ (N-America); climate Dfb] and lower mean temperature $\left[9.7-11.1^{\circ} \mathrm{C}\right.$ (Netherlands and North Caucasus) vs. $15.3^{\circ} \mathrm{C}$ (Mexico); climate $\mathrm{Cfb}]$. In the geographical distribution of plants, the environmental factors involved influence the physi- ological reaction of individuals with their limit of tolerance to the conditions prevailing in the environment and, if individuals are genetically pre-adapted, they could extend the occupied area. Our findings will open an avenue for future researchers to investigate the possible causes of existence of such species under such low precipitation 
and temperature. As this species could have an ecological impact on autochthonous floras, as well as it could have multiple benefits in agriculture, pharmaceutical and cosmetic industries, it is critical to address its distribution and spread.

\section{Funding}

Tere was no funding for present research.

\section{Acknowledgements}

Thanks are due to Directors and Curators of all quoted herbaria for their support. Special thanks are due to Michail Orlov (Михаил Орлов) for the permission to reproduce his picture of Amaranthus hypochondriacus from Soči (Sochi) city, to Filip Verloove (Botanic Garden Meise, Belgium) for help us in some literature work concerning Netherlands, and to Sergei L. Mosyakin (M.G. Kholodny Institute of Botany, National Academy of Sciences of Ukraine, Kyiv, Ukraine) who provided some East European publications, help us in the translation from languages using the Cyrillic script, and discussed some issues about the alien status of Amaranthus hypochondriacus in Belarus and the North Caucasus.

The research is part of the $\mathrm{PhD}$ thesis of $\mathrm{ANH}$.

Duilio lamonico (D) https://orcid.org/0000-0001-5491-7568

Paola Fortini (D) https://orcid.org/0000-0003-4481-2126

Amara Noor Hussain (D) https://orcid.org/0000-0003-0721-9227

\section{Reference}

Bao, B., Clemants, S. E., \& Borsch, T. (2003). Amaranthus L. In Z. Y. Wu, P. H., Raven, \& D. Y., Hong (Eds.), Flora of China 5 (pp. 415-429). Science Press and Missouri Botanical Garden Press.

Bayón, N. D. (2015). Revisión taxonómica de las especies monoicas de Amaranthus (Amaranthaceae): Amaranthus subg. Amaranthus y Amaranthus subg. Albersia. Annals of the Missouri Botanical Garden, 101(2), 261-383.

Boiko, G. V., \& Kolomiychuk, V. P. (2015). Addition to the flora of the northern coast of the Sea of Azov [Доповнення до флори північного узбережжя Азовського моря.]. Ukrainan Journal of Botany, 72(4), 340-343. [In Ukrainian]

Capelli, G. (2015). The Marrana of the Mariana water. A stream at the service of the Popes. Subterranean Waters-Italian Journal of Groundwater, 4(4), 79-82. https://doi.org/10.7343/as-135-15-0162

Carmona Pinto, W., \& Orsini Velázquez, G. (2010). Synopsis of the subgenus Amaranthus (Amaranthus, Amaranthaceae) in Venezuela. Acta Botanica Venezuelica, 33(2), 329-355.
Costea, M., Sanders, A., \& Waines, G. (2001). Preliminary results towards a revision of the Amaranthus hybridus complex (Amaranthaceae). Sida, 19, 931-974.

Das, S. (2016). Amaranthus: A Promising Crop of Future. Springer Nature.

Dirkse, G. M., Barendse, R., \& Abbink-Meijerink, C. G. (1983). Amaranthus bouchonii Thell. (Franse amarant) en $A$. hybridus $\mathrm{L}$. (Groene amarant) in Nederland. Gorteria, 24, 69-80.

Dubovik, D. V., Savczuk, S. S., Skuratovich, A. N., Lebedko, V. N., \& Saulov, A. O. (2018). New distribution data some rare and protected species vascular plants of the flora of Belarus [Новые данные o распространении некоторых редких и охраняемых видов сосудистых растений флоры Беларуси]. Botanika (issledovaniya) (Minsk), 47, 32-51. [In Belorusian]

Dubovik D. V. (2019). Potentially invasive plant species in the flora of Belarus. In Ö. K., Aksoy, M. Azmaz, Y. Katılmıș, \& R. Mammadov (Eds.), Materials of the International Scientific Conference "Flora and Vegetation in a Changing World: Problems of Studying, Preserving and Rational Use" (pp. 196-202). Kolorgrad. [In Russian].

Duistermaat, L. (2020). Heukel' Flora van Nederland. Noordhoff, Naturalis.

Euro+Med (2006-). Euro+Med PlantBase - the information resource for Euro-Mediterranean plant diversity. Retrieved July 14, 2021, from http://ww2.bgbm.org/EuroPlusMed/00Rf.asp.

Galasso, G., Conti, F., Peruzzi, L., Ardenghi, N. M. G., Banfi, E., Celesti-Grapow, L., Albano, A., Alessandrini, A., Bacchetta, G., Ballelli, S., Bandini Mazzanti, M., Barberis, G., Bernardo, L., Blasi, C., Bouvet, D., Bovio, M., Cecchi, L., Del Guacchio, E., Domina, G., Fascetti, S., Gallo, L., Gubellini, L., Guiggi, A., Iamonico, D., Iberite, M., Jiménez-Mejías, P., Lattanzi, E., Marchetti, D., Martinetto, E., Masin, R. R., Medagli, P., Passalacqua, N. G., Peccenini, S., Pennesi, R., Pierini, B., Podda, L., Poldini, L., Prosser, F., Raimondo, F.M., Roma-Marzio, F., Rosati, L., Santangelo, A., Scoppola, A., Scortegagna, S., Selvaggi, A., Selvi, F., Soldano, A., Stinca, A., Wagensommer, R. P., Wilhalm, T., \& Bartolucci, F. (2018). An updated checklist of the vascular flora alien to Italy. Plant Biosystems, 152(3), 556-592.

Heap, I. (2014). Herbicide resistant weeds. In D. Pimentel, \& R. Peshin (Eds.), Integrated pest management (pp. 281-301). Springer.

Hernández-Ledesma, P., Berendsohn, W. G., Borsch, T., Mering, S. von, Akhani, H., Arias, S., Castañeda-Noa, I., Eggli, U., Eriksson, R., Flores-Olvera, H., Fuentes-Bazán, S., Kadereit, G., Klak, C., Korotkova, N., Nyffeler, R., Ocampo, G., Ochoterena, H., Oxelman, B., Rabeler, R. K., Sanchez, A., Schlumpberger, B. O., \& Uotila, P. (2015). A taxonomic backbone for the global synthesis of species diversity in the angiosperm order Caryophyllales. Willdenowia 45. 281-383.

Heukels, H. (1883). Schoolflora voor Nederland. Noordhoff.

Heukels, H. (1900). Geillustreerde schoolflora voor Nederland. Noordhoff.

Iamonico, D. (2010a). Biology, life-strategy and invasiveness of Amaranthus retroflexus L. (Amaranthaceae) in central Italy: preliminary remarks. Botanica Serbica, 34(2), 137-145.

Iamonico D. (2010). On the presence of Amaranthus polygonoides L. (Amaranthaceae) in Europe. Phyton, 50(2), 205-219.

Iamonico, D. (2015a). Taxonomic revision of the genus Amaranthus (Amaranthaceae) in Italy. Phytotaxa, 199(1), 1-84. 
Iamonico, D. (2015b). Amaranthaceae. In Euro+Med Plantbase - the information resource for Euro-Mediterranean plant diversity. Retrieved July 14, 2021, from http://ww2.bgbm.org/EuroPlusMed/RegionalTaxon.asp?PTNameFK=890\&PTRefFk=7300000\&Name=Amaranthus.

Iamonico, D. (2016a). Nomenclature survey of the genus Amaranthus (Amaranthaceae). 3. Names linked to the Italian flora. Plant Biosystems, 150(3), 519-531.

Iamonico, D. (2016b). Nomenclatural survey of the genus Amaranthus (Amaranthaceae) 4. Detailed questions arising around the name Amaranthus gracilis. Botanica Serbica, 40(1), 61-68.

Iamonico, D. (2016c). Nomenclature survey of the genus Amaranthus (Amaranthaceae) 5. Moquin-Tandon's names. Phytotaxa, 273(2), 81-114.

Iamonico, D. (2017). Amaranthus $\times$ romanus (Amaranthaceae), hybr. nov. Phytotaxa, 295(1), 89-91. https://doi.org/10.11646/ phytotaxa.295.1.9

Iamonico, D. (2020a). Nomenclature survey of the genus Amaranthus (Amaranthaceae s.s.) 8. About Amaranthus polygonoides s.l. and A. anderssonii, two related taxa described from the tropical regions of America, with notes on their taxonomy. Acta Botanica Mexicana, 127, e1687.

Iamonico, D. (2020b). A nomenclatural survey of the genus Amaranthus (Amaranthaceae). 7. Wildenow's names. Willdenowia, 50(1), 147-155.

Iamonico, D. (2020c). A nomenclatural survey of the genus Amaranthus (Amaranthaceae). 11. dioecious Amaranthus species belonging to the sect. Saueranthus. Darwiniana, 8(2), 567-575.

Iamonico, D. (2020d). A nomenclatural survey of the genus Amaranthus (Amaranthaceae) 10: What is Amaranhus commutatus? Thaiszia, 30(2), 187-196. https://doi.org/10.33542/TJB2020-2-03

Iamonico, D., \& Galasso, G. (2018). New nomenclatural changes for hybrids of Amaranthus (Amaranthaceae s. str.). Phytotaxa, 340 (2), 196-196. https://doi.org/10.11646/phytotaxa.340.2.11

Iamonico, D., \& Palmer, J. (2020). Nomenclature survey of the genus Amaranthus (Amaranthaceae). 6. Names linked to the Australian flora. Austtralian Journal of Botany, 33(2), 169-173.

Iamonico, D., Nicolella G., \& Noor Hussain, A. (2021). Amaranthus muricatus (Moq.) Gillies. ex Hieron (Amaranthaceae). In G., Galasso, G., Domina., S., Andreatta., E., Argenti, G., Bacchetta, S., Bagella, E., Banfi, D., Barberis, S., Bardi, S., Barone, F., Bartolucci, A., Bertolli, N., Biscotti, F., Bonali, F., Bovini, D., Bonsanto, Brundu, G., Buono, S., Caldarella, O., Calvia, G., Cambria, S., Campus, G., Caria, M. C., F., Conti, A., Coppi, D., Dagnino, E., Del Guacchio, E., Di Pristina, E., Farris, G., Ferretti, F., Festi, M., Fois, F., Furlani, D., Gigante, R., Guarino, L., Gubellini, N., Hofmann, D., Iamonico, P., Jiménez-Mejias, A., L. A. La Rosa, V., Laface, A., Lallai, L., Lazzaro, M., Lonati, V., Lozano, F., Luchino, J., Lupoletti, S., Magrini, A., Mainetti, D., Marchetti, P., Marenzi, M., Marignani, M., Martignoni, G., Mei, F., Menini, M., Merli, M., Mugnai, C. M., Musarella, G., Nicolella, A., Noor Hussain, N., Olivieri, S., Orlandini, S., Peccenini, L., Peruzzi, A., Pica, N., Pilon, L., Pinzani, M., Pittarello, L.,Podda, M.,Probo, F.,Prosser, C., Raffaelli, S., Ravetto Enri, G., Rivieccio, L.,Rosati, S., Sarmati, F., Scafidi, F., Selvi, A. N., Sennikov, G., Sotgiu Cocco, G., Spampanato, A., Stinca, G., Tavilla, V.,Tomaselli, D., Tomasi, G., Tomasi, M.,Trenchi, C., Turcato, F., Verloove, D., Vicini, M., Villa, R. P. Wagensommer, \& L., Lastrucci (Eds.), Notulae to the Italian alien vascular flora 11. Italian Botanist 11, 97-98. https://doi. org/10.3897/italianbotanist.11.68063
Ivanov, A. L. (2019). Conspectus Florae Caucasi Rossicae (plantae vasculares) [Конспект флоры Российского Кавказа]. NCFU. [In Russian]

Köppen, W. (1936). Das geographisca System der Klimate. In W. Köppen, \& G., Geiger (Eds.), Handbuch der Klimatologie 1. C (pp. 1-44). Gebrüder Borntraeger.

Kukk, T. (1999). Eesti Taimestik. Teaduste Akadeemia Kirjastus.

Laface, V. L. A., Musarella, C. M., Spampinato, G., Iamonico, D., Noor Hussain, A., Fortini, P., Peruzzi, L., Giardini, M., Angeloni, D., Meneguzzo, E., Meneguzzo, A., Banfi, E., Busnardo, G., Galasso, G., Kleih, M., Wallnöfer, B., Bernardo, L., Roma-Marzio, F., Brentan, M., \& Marcucci, R. (2020). Nuove segnalazioni floristiche italiane 9. Flora vascolare (67-78). Notiziario della Società Botanica Italiana, 4, 1-5.

Linnaeus, C. (1753). Species plantarum 2. Laurentii Salvii.

Loban, S. E. (2016). Perspective varieties of Genus Amaranthus L. in collection of the Central Botanical Garden of the NAS OF Belarus, Kolograd. [in Russian]

Loban, S. E., \& Kot, A. A. (2017). Introduction the study of plants of the genus Amarantus L. in the Central botanical garden of NAS of Belarus [Интродукционное изучение растений рода Amaranthus L. в условиях Центрального ботанического сада НАН Беларуси], Medisont. [In Russian].

Mikhailovich, G. Y., \& Akramovich, M. A. (2017). Records of new and rare alien species of plants in flora of the Bashkortostan Republic [Находки новых и редких адвентивных видов растений во флоре Республики Башкортостан]. Fitoraznoobraziye Vostochnoy Yevropy, 11, 54-62. [In Russian]

Mosyakin S. L. 1996. Amaranthus. In N. N. Tzvelev (Ed.), Flora Europae Orientalis 9 (pp. 11-18). Mir i Sem'ya-95. [In Russian]

Mosyakin, S. L., \& Robertson, K. R. (1996). New infrageneric taxa and combinations in Amaranthus (Amaranthaceae). Annales Botanici Fennici, 33, 275-281.

Mosyakin, S. L., \& Robertson, K. R. (2003). Amaranthus L. In Flora of North America Editorial Committee (Eds.), Flora of North America North of Mexico 4 (pp. 410-435). Oxford University Press.

Naturalis. (2021). Amaranthus hypochondriacus L. Retrieved April 8, 2021, from https://bioportal.naturalis.nl/taxon/Amaranthus_ hypochondriacus/term=Amaranthus + hypochondriacus\&from $=0$.

NDFF (2015). NDFF Verspreidingsatlas. FLORON Verspreidingsatlas Vaatplanten. Amaranthus hypochondriacus L. Retrieved April 8, 2021, from https://www.verspreidingsatlas.nl/5572

Pärtel, J., Pärtel M., \& Wäldchen, J. (2021). Plant image identification application demonstrates high accuracy in Northern Europe. $A o B$ Plants, 13(4), plab050. https://doi.org/10.1093/aobpla/plab050

Plants of Belarus (2003-2021). Cultivated Plants: Anthophyta: Dicotyledones. Retrieved April 10, 2021, from http://hbc.bas-net.by/ plantae/eng/default hp?aaafam=eNortjI0tlJyzE0sSswryUhMTk1MVb IGXDBJOAbm\&gen $=$ eNortrK0UtJVSE_NKy1W0FWyBlwwJckEXF w\%2C\&otdel=eNortjIytVJyzCvJyC_IqCxJtFJwyUzOL6nMSU3Jz0stVrIGXDC-QQue\&sort=1\&type=vyr\&prizn=.

POWO. (2021-). Plants of the World Online. Amaranthus powellii S.Watson. Retrieved April 8, 2021, from http://www. plantsoftheworldonline.org/taxon/urn:lsid:ipni.org:names:319617-2. 
Rivas-Martínez, S., Rivas-Sáenz, S., Penas, A., Costa, M., \& SánchezMata, D. (2007a). Computerized bioclimatic Maps of the world: Bioclimates of North America. Centro de investigaciones Fitosociológica.

Rivas-Martínez, S., Penas, Á., \& Diaz, T. E. (2007b). Bioclimatic map of Europe. Cartographic Service, University of León.

Euro+Med (2006-). Euro+Med PlantBase - the information resource for Euro-Mediterranean plant diversity. Retrieved July 14, 2021, from http://ww2.bgbm.org/EuroPlusMed/00Rf.asp.

SANBI. (2012). Amaranthus hypochondriacus L. In National Assessment: Red List of South African Plants version 2014.1. Retrived April 17, 2021, from http://www.ville-ge.ch/musinfo/bd/cjb/africa/ details.php?langue $=$ an $\&$ id $=332$.

Sauer, J. D. (1967). The grain amaranths and their relatives: a revised taxonomic and geographic survey. Annals of the Missouri Botanical Garden, 54(2), 103-137.

Stafleu, F. A., \& Cowan, R. S. (1976). Taxonomic literature $(A-G)$ (2nd ed.). Scheltema \& Holtema.

Stetter, M. G., \& Schmid, K. J. (2017). Analysis of phylogenetic relationships and genome size evolution of the Amaranthus genus using GBS indicates the ancestors of an ancient crop. Molecular phylogenetics and evolution, 109, 80-92.

Menitsky, Y. I. 2012: Amaranthaceae. In A. L. Takhtajan, G. L. Kudryashova, \& I. V. Tatanov (Eds.), Conspectus Florae Caucasi 3(2) [Конспект флоры Кавказа] (pp. 218-221). KMK Scientific Press. [In Russian]

Tamis, W. L. M., van der Meijden, R., Runhaar, J., Bekker, R. M., Ozinga, W. A., Odé, B., \& Hoste, I. (2003). Standaardlijst van de Nederlandse flora. Gorteria, 30(2004), 101-195.

Thiers, B. (2021-). Index herbariorum, a global directory of public herbaria and associated staff. Retrieved March 30, 2021, from http:// sweetgum.nybg.org/ih/.
Tranel, P. J., \& Trucco, F. (2009). 21st-century weed science: a call for Amaranthus genomics. In C. N. Stewart Jr. (Ed.), Weedy and invasive plant genomics (pp. 53-81). Wiley-Blackwell.

Vlasava N. B. Yukhimuk A. N., \& Spiridovich E. V. (2010). Genetic differentiation of Amaranthus spp. cultivars on the basis of RAPD- and ISSR-markers. In V. F. Pivovarov (Ed.), Current trends in vegetable breeding and seed production. Traditions and perspectives, IIth International Scientific Research Conference 1 (pp. 162-172). Russian Academy of Science. http://doi.org/10.13140/RG.2.1.3475.3681

Waselkov, K. E., Boleda, A. S., \& Olsen, K. M. (2018). A phylogeny of the genus Amaranthus (Amaranthaceae) based on several low-copy nuclear loci and chloroplast regions. Systematic Botany, 43, 439-458.

Tzvelev, N. N. (2012). Amaranthaceae. In N. N. Tzvelev, \& D. V. Geltman (Eds.), Conspectus Florae Europae Orientalis 1 (pp. 265-270). KMK Scientific Press. [In Russian]

Waarneming. (2021). Waarneming.nl. Amaranthus hypochondriacus L. Retrieved July 14, 2021, from https://waarneming.nl/species/154169/ statistics/.

Zernov, A. S. (2006). Flora of the Northwestern Caucasus. KMK Scientific Press. [in Russian]

Zernov, A. S. (2013). Illustrated flora of the Southern stretch of the Russian Black Sea coast [Иллюстрированная флора юга Российского Причерноморья.]. KMK Scientific Press. [In Russian]

Zepner, L., Karrasch, P., Wiemann, F., \& Bernard, L. (2021). ClimateCharts. net-an interactive climate analysis web platform. International journal of digital Earth, 14(3), 338-356.

Zviagintseva, K. A. (2013). The new finds of alien plants in the flora of Kharkiv [Знахідки адвентивних рослин у флорі м. Харкова]. Ukrainan Journal of Botany, 70(6), 772-775. [In Ukrainian]. 